\title{
HAVING CONTACT HISTORY WITH TB ACTIVE CASES AND MALNUTRITION AS RISK FACTORS OF TB INCIDENCE: A CROSS-SECTIONAL STUDY IN NORTH SUMATERA, INDONESIA
}

\author{
Wiwit Aditama ${ }^{1 *}$, Frans Yosep Sitepu ${ }^{2 \star *}$ and Elpiani Depari ${ }^{3}$ \\ ${ }^{1}$ Department of Environmental Health, Banda Aceh Polytechnic of Health of the Ministry of Health, Indonesia \\ 2Provincial Health Office of North Sumatera, Indonesia \\ ${ }^{3}$ GrandMed Hospital, Deliserdang, North Sumatera, Indonesia
}

Corresponding author 1: Wiwit Aditama

Email: widnad78@yahoo.co.id

Corresponding author 2: Frans Yosep Sitepu

Email: franz_sitepu@yahoo.co.uk

\begin{abstract}
Tuberculosis (TB) is one of the leading causes of morbidity and mortality. It is carrying a heavy public health problem burden in Indonesia. This study aimed to determine the risk of poor knowledge of TB, socioeconomic status, malnutrition and contact history with TB cases with the incidence of TB in Medan. This was a cross sectional study conducted between May - August 2019 in Medan municipality, in the three highest TB cases incidence public health centers (puskesmas). Structural interviews were conducted to solicit demographic data, clinical data, as well as the risk factors. Logistic regression was conducted to assess the potential risk factors associated with the infection. We enrolled 260 clinically suspected cases of TB, comprising 135 (51.9\%) cases positive for TB and 125 (48. 1\%) cases negative for TB. In multivariate model, those who had contact history with active TB cases and those who malnourished had higher odds of having TB infection, with adjusted odds ratio (aOR): 5.58 (95\%Cl:3.13-9.93) and aOR: 3.36 (95\% Cl: 1.876.02), respectively. Having contact history with TB active case and malnutrition were the most significant risk factors of TB incidence in Medan municipality, North Sumatera, Indonesia. Therefore, educating patients on the importance of cough or sneezes etiquette procedures including use of face masks to minimize the risk of infection.
\end{abstract}

Keywords: contact history, malnutrition, TB, cross sectional

\section{INTRODUCTION}

Tuberculosis (TB) is a communicable disease that caused by the bacillus Mycobacterium tuberculosis. ${ }^{(1,2)}$ According to the world health organization (WHO), TB is a major public health problem and one of the greatest threats in the world. It is one of the top 10 causes of death (1) and estimated that about a quarter of the world's population is infected with Mycobacterium tuberculosis and thus at risk of developing the disease.

TB is one of the major causes of morbidity and mortality in Indonesia carrying a heavy public health problem burden. ${ }^{(3-5)}$ Indonesia is one of the eight countries accounted for two thirds of the global total TB cases in the world. The country also ranks ninth amongst the 20 high burden TB countries with TB incidence rate of 341 per 100,000 populations, however, only $45 \%$ of these cases are detected and reported to the National TB Program (national target was $70 \%$ ). ${ }^{(3)}$

In North Sumatera province, the case detection rate (CDR) was only $50 \%$, and success rate (SR) was
91.2\% (national target was >95\%). Medan municipality is the capital of North Sumatera province and the highest TB incidence in the province. Medan is the third largest city in Indonesia with the number of population more than 2.2 million people. Medan municipal government is fully committed in the prevention of TB in the city. This commitment is outlined in Medan Mayor Regulation (Peraturan Walikota) No.85 / 2017 concerning TB Prevention in November 2017. TB cases in Medan which were discovered and reported from 2013 to 2016 were 5,333 cases; 5,773 cases, 6,421 cases, and 7,431 cases respectively. While multidrug resistant TB cases to date were 299 cases. ${ }^{(6,7)}$

However, TB is still a health problem and found in all areas of the public health centers (puskesmas). The scope of the causes of TB problems in Medan is very multi-factor such as the low level of community knowledge, socioeconomic status, malnutrition and having contact history with pulmonary TB sufferers. Having contact history with TB cases was risk factor for TB. Household contacts are highly susceptible to acquire TB infection from the index cases because of their 
close proximity. ${ }^{(8,9)}$ Many studies have concluded that malnutrition increases the risk for TB infection because of impaired immune response. ${ }^{(1-3)}$

This study aimed to determine the risk of poor knowledge of TB, socioeconomic status, malnutrition and contact history with TB cases with the incidence of TB in Medan.

\section{METHODS}

\section{Study design and setting}

This was a cross sectional study conducted between May - August 2019 in Medan municipality. The city is the capital of North Sumatera province. The study was conducted in the three public health centers (PHC) with highest TB incidence in Medan municipality: Medan Area Selatan PHC, Glugur Darat PHC and Teladan PHC.

\section{Study procedures}

All clinically suspected cases of TB who came to the three PHCs during the data collection period were interviewed. Face to face interview were conducted to all the respondents. A structured questionnaire consisting of respondent characteristics and demographic information was used. Respondent related information contained age, gender, knowledge of TB and its prevention, nutritional status, socioeconomic status and history of contacts with TB cases. To measure the knowledge regarding $T B$, the questions according to the guideline of prevention and control of TB by the Ministry of Health of Indonesia.

The respondents' knowledge score about TB was calculated as the sum of the response scores. The number of questions regarding the respondent's knowledge was 20 questions. Each correct respondent's answer will get a score of 1 (one) and 0 (zero) for each incorrect/unknown answer. The minimum score of the respondent is 0 (zero) and 20 for the maximum score. The level of knowledge was grouped into "adequate" and "inadequate" based on the $80 \%$ cut-off point. The Cronbach's alpha coefficient of the knowledge questionnaire was 0.75 in our sample, indicating acceptable internal consistency.

Nutritional status counted by measuring the body mass index (BMI) of the respondents. We calculated BMI as weight in kilograms divided by the square of height in meters. If the result is underweight $(\mathrm{BMI}<18.5)$ or overweight $(\mathrm{BMI}>25)$ the respondent will be grouped into malnutrition. Socioeconomic status by measuring the monthly income of the respondents compare with the regional minimum wage of Medan municipality. If the respondent's monthly income was below the regional minimum wage of Medan it will be grouped into low socioeconomic status. Contact history measuring by asking the respondents with close contact history with TB cases in the household, schools, or working places.

During the study period there were 260 suspected TB patients who came to the study sites. Sputum samples were collected from all the suspected cases by trained laboratory assistant. The standard procedures on the collection of sputum sample for TB suspect cases (i.e. spot- early morning - spot). Spot sample was collected at the time of first visit of patient to the PHCs and early morning sputum was collected the next day.

\section{Data analysis}

Variables associated with $T B$ in the univariate analysis $(p<0.05)$ were included for the multivariate analysis. A 95\% confidence interval and a $5 \%$ level of significance were used to interpret statistical significance. The $p$-values < 0.05 were considered significant. In the multivariate analysis, we included the knowledge of TB variable because it is one of the major independent variables of the present study.

\section{Ethical considerations}

Health research ethics commission of Banda Aceh Polytechnic of Health of the Ministry of Health, Indonesia (Ref No LB.02.03/10267/2019) approved the project protocol and questionnaires. Written informed consent was obtained from all participants.

\section{RESULTS}

\section{Characteristics of subjects}

We enrolled 260 clinically suspected cases of TB, comprising $135(51.9 \%)$ cases positive for TB and $125(48.1 \%)$ cases negative for TB. There was no significance difference in characteristics of subjects (Table 1 ). 
Table 1. Characteristic of subjects $(n=260)$

\begin{tabular}{lccc}
\hline \multicolumn{1}{c}{ Variables } & TB $(\%)$ & Not TB $(\%)$ & p-value \\
\hline Gender & & & 0.41 \\
Male & $73(54.1)$ & $56(44.8)$ & \\
Female & $62(45.9)$ & $69(55.2)$ & \\
& & & 0.68 \\
Age group & $32(23.7)$ & $41(32.8)$ & \\
20-30 year & $51(37.8)$ & $58(46.4)$ & \\
31-40 year & $52(38.5)$ & $26(20.8)$ & \\
>40 year & & & \\
& & $23(18.4)$ & \\
Level of education & $35(25.9)$ & $70(56.0)$ & \\
Primary & $68(50.4)$ & $32(25.6)$ & \\
Secondary & $32(23.7)$ & & \\
Tertiary & & $43(34.4)$ & \\
& & $26(20.8)$ & \\
Occupation & $55(40.8)$ & $56(44.8)$ & \\
Businessman & $28(20.7)$ & & \\
Employee & $52(38.5)$ & & \\
Housewife & & & \\
\hline
\end{tabular}

Table 2. Association between knowledge of TB, socioeconomic status, malnutrition and contact history with TB incidence

\begin{tabular}{|c|c|c|c|c|c|}
\hline Variables & TB & Not TB & $p$-value & OR & $95 \% \mathrm{Cl}$ \\
\hline \multicolumn{6}{|l|}{ Knowledge of TB } \\
\hline Inadequate & 75 & 72 & 0.84 & 0.92 & $(0.56-1.50)$ \\
\hline Adequate & 60 & 53 & & & \\
\hline \multicolumn{6}{|c|}{ Socioeconomic status } \\
\hline Low & 73 & 41 & 0.01 & 2.41 & $1.46-3.99$ \\
\hline High & 62 & 84 & & & \\
\hline \multicolumn{6}{|l|}{ Malnutrition } \\
\hline Yes & 100 & 46 & 0.01 & 4.91 & $2.89-8.33$ \\
\hline No & 35 & 79 & & & \\
\hline \multicolumn{6}{|l|}{ Contact history } \\
\hline Yes & 95 & 31 & $<0.01$ & 7.20 & $4.16-12.47$ \\
\hline No & 40 & 94 & & & \\
\hline
\end{tabular}

Table 3. Multivariate analysis of risk factors of TB incidence

\begin{tabular}{lcccc}
\hline \multicolumn{1}{c}{ Variables } & $\mathrm{B}$ & $\mathrm{p}$-value & $\mathrm{OR}$ & $95 \% \mathrm{Cl}$ \\
\hline Malnutrition & 1.21 & 0.01 & 3.36 & $1.87-6.02$ \\
Contact history & 1.72 & $<0.01$ & 5.58 & $3.13-9.93$ \\
\hline
\end{tabular}




\section{DISCUSSIONS}

In this study we found that the risk factors of TB incidence in Medan were having contact history with TB cases and malnutrition. Having contact history with TB cases was the strongest risk factor for $T B$ incidence in the study. TB contacts were people who had close contact for any length of time with active TB case. A close contact of a person with active TB has a high risk of becoming infected and developing of the disease. The risk of TB infection is greatest if the contact is close and prolonged. ${ }^{(10,11)}$ TB contacts should be investigated systematically and actively to prevent TB infection in the community. ${ }^{(9,12,13)}$

When there is a TB case it can increase risk of TB to other members of the household. ${ }^{(10,11,14)}$ TB is transmitted from person to person through the air. The Mycobacterium tuberculosis is carried in airborne particles, after exposure to airborne the droplets some contacts will be infected and some of these will go on to develop the disease. ${ }^{(10,15)}$ The study revealed that the cases had contact history with TB active cases. Therefore, educating patients on respiratory hygiene and the importance of cough or sneezes etiquette procedures including use of face masks to minimize the risk of infection. ${ }^{(15)}$ This findings is consistent with previous studies that have demonstrated an association between having contact history with TB cases and the incidence of TB. ${ }^{(8,9,11,12,14,16)}$

Malnutrition was another risk factor of TB infection. ${ }^{(2,16-18)}$ The association between malnutrition and TB incidence is bi-directional. TB predisposes the patient to malnutrition and malnutrition increases the vulnerability of developing the disease. ${ }^{(18,19)}$ Epidemiological studies have shown that malnutrition affects genetic expression and impaired immune response, which are predisposing factors for tuberculosis progression. $(2,16,18)$ Malnutrition is one of important risk factors for TB because it profoundly affects cell-mediated immunity (CMI). It is a condition when an immune response that does not involve antibodies; $\mathrm{CMI}$ also the principle host defense against TB. $\left.{ }^{(18,20}\right)$ This finding is consistent with other studies where individuals who malnourished had a higher risk of acquiring TB infection compared to those who not malnourished. ${ }^{(2,17-19)}$

In the multivariate analysis we found that socioeconomic status was not related to TB incidence. However, in the bivariate analysis socioeconomic status was related to the incidence of TB. As much as 73 out of $135(54.07 \%)$ TB cases were low socioeconomic status. People with low socioeconomic status have a higher risk of being infected and a higher incidence of TB. Most researchers agree on the general association between TB and socioeconomic conditions, but no direct cause and effect relationship has been demonstrated. It appears that although poor people have a higher risk of becoming infected, there is no direct evidence that the infected poor have a higher risk of developing disease. ${ }^{(2,5,16,21)}$

In addition, another risk factors of TB incidence were physical conditions of house environment such as ventilation, lighting, occupancy density, humidity, temperature and type of floor. ${ }^{(22)}$ Low socioeconomic status was related to not eligible of physical conditions of house environment. Many studies found that a poor physical conditions of house environment can become a way for disease transmission. It is because the high intense interaction between humans and the environment, especially for people who spend a lot of time at home. ${ }^{(8,16,23)}$ However, we did not investigate the physical conditions of house environment of the respondents. Therefore, this was the limitation of the study.

Finally, as the result of the study we could not find the relationship between knowledge of $T B$ and TB incidence. However, we found that 147 out of $260(56.54 \%)$ respondents were inadequate knowledge of TB. Respondents' knowledge of TB is an important variable. Inadequate respondents' knowledge of TB causes not only the delay in seeking diagnosis but also poor treatment adherence. ${ }^{(1,4)}$ The relatively poor knowledge of TB among the respondents showed that there is a need to implement activities that would educate the public about the disease.

\section{CONCLUSIONS}

We can conclude that having contact history with TB active case and malnutrition were the most significant risk factors of TB incidence in Medan municipality, North Sumatera, Indonesia. Therefore, educating patients on the importance of cough or sneezes etiquette procedures including use of face masks to minimize the risk of infection.

\section{ACKNOWLEDGMENT}

We would like to acknowledge to the head and all the TB program staffs of Medan Area Selatan PHC, Glugur Darat PHC, Teladan PHC, and all the participants for their significant contribution.

\section{CONFLICT OF INTEREST}

The authors declare that they have no competing financial interest. This is a self-funded research. 


\section{REFERENCES}

1. World Health Organization. Global Tuberculosis Report 2019. World Health Organization. 2019.

2. Narasimhan P, Wood J, Macintyre CR, Mathai D. Risk factors for tuberculosis. Pulm Med. 2013;2013.

3. Kementerian Kesehatan Republik Indonesia. Current status of integrated community based TB service delivery and the Global Fund work plan to find missing TB cases. Indonesia National TB Program. 2017.

4. Setiarni SM, Sutomo AH, Hariyono W. Hubungan Antara Tingkat Pengetahuan, Status Ekonomi Dan Kebiasaan Merokok Dengan Kejadian Tuberkulosis Paru Pada Orang Dewasa Di Wilayah Kerja Puskesmas Tuan-Tuan Kabupaten Ketapang Kalimantan Barat. J Kesehat Masy (Journal Public Heal. 2013;5(3).

5. Soetanto $\mathrm{H}$, Pakasi TA. Hubungan antara Faktor Sosio Ekonomi Ibu terhadap Pengetahuan Mengenai Tuberkulosis. eJournal Kedokt Indones. 2015;3(1).

6. Medan DK. 2016, Kasus TB di Kota Medan Capai 7431 Kasus. http: / /dnaberita.com [Internet]. 2017; Available from: http://dnaberita.com/2017/12/15/20 16-kasus-tb-di-kota-medan-capai7431-kasus/

7. Winata R. Wakil Walikota Luncurkan Perwal Penanggulangan Penyakit TB. http://www.medanbisnisdaily.com [Internet]. 2017; Available from: http://www.medanbisnisdaily.com/ne ws/online/read/2017/11/14/13230/w akil_walikota_luncurkan_perwal_pena nggulangan_penyakit_tb/

8. Laghari M, Sulaiman SAS, Khan $A H$, Talpur BA, Bhatti Z, Memon N. Contact screening and risk factors for TB among the household contact of children with active TB: A way to find source case and new TB cases. BMC Public Health. 2019;19(1):1-10.

9. Gupta M, Saibannavar AA, Kumar V. Household symptomatic contact screening of newly diagnosed sputum smears positive tuberculosis patientsAn effective case detection tool. Lung India. 2016;33(2):159-62.
10. Report MW. Guidelines for the investigation of contacts of persons with infectious tuberculosis. Recommendations from the National Tuberculosis Controllers Association and CDC. MMWR. 2005;54(RR-15):1-47.

11. Reichler MR, Khan A, Sterling TR, Zhao $\mathrm{H}$, Moran J, McAuley J, et al. Risk and timing of tuberculosis among close contacts of persons with infectious tuberculosis. J Infect Dis. 2018;218(6):1000-8.

12. Verdier JE, de Vlas SJ, KidgellKoppelaar ID, Richardus JH. Risk factors for tuberculosis in contact investigations in Rotterdam, the Netherlands. Infect Dis Rep. 2012;4(2):101-5.

13. Bhat J, Rao VG, Sharma RK, Muniyandi M, Yadav R, Bhondley MK. Investigation of the risk factors for pulmonary tuberculosis: A case-control study among Saharia tribe in Gwalior district, Madhya Pradesh, India. J Dent Educ [Internet]. 2017;146(11):97-104. Available from: http://www.ncbi.nlm.nih.gov/pubme d/23144490

14. Fox GJ, Barry SE, Britton WJ, Marks GB. Contact investigation for tuberculosis: a systematic review and meta-analysis. Eur Respir J. 2013;41(1):140-56.

15. Wang $X N$, He TL, Geng MJ, Song YD, Wang JC, Liu $M$, et al. Prevalence of and risk factors for tuberculosis among healthcare workers in Chinese tuberculosis facilities. Infect Dis Poverty. 2018;7(1):1-11.

16. Hajarsjah N, Daulay RM, Ramayani OR, Dalimunthe W, Daulay RS, Meirina F. Tuberculosis risk factors in children with smear-positive tuberculosis adult as household contact. Paediatr Indones. 2018;58(2):66-70.

17. Jaganath D, Mupere E. Childhood tuberculosis and malnutrition. J Infect Dis. 2012;206(12):1809-15.

18. Cegielski JP, McMurray DN. The relationship between malnutrition and tuberculosis: Evidence from studies in humans and experimental animals. Int J Tuberc Lung Dis. 2004;8(3):286-98.

19. Feleke BE, Feleke TE, Biadglegne F. Nutritional status of tuberculosis patients , a comparative crosssectional study. BMC Pulm Med. 
2019;19(182):1-9.

20. Wing EJ, Remington JS. Cell-Mediated Immunity and Its Role in Resistance to Infection. West J Med. 1977;126(January):14-31.

21. Africa FS. The Relationship between Socioeconomic Factors and Pulmonary Tuberculosis. Int J Epidemiol. 1991;20(2):435-40.

22. Siroka A, Law I, Macinko J, Floyd K, Banda RP, Hoa NB, et al. The effect of household poverty on tuberculosis. Int J Tuberc Lung Dis. 2016;20(12):1603-8.
23. Aditama W, Sitepu FY, Saputra R. Relationship between Physical Condition of House Environment and the Incidence of Pulmonary Tuberculosis, Aceh , Indonesia. Int J Sci Healthc Res. 2019;4(March):227 